\title{
Influence of Sulfur Induced Stress on Oxidative Status and Antioxidative Machinery in Leaves of Allium cepa $\mathbf{L}$.
}

\author{
Neelam Chandra and Nalini Pandey \\ Plant Nutrition and Stress Physiology Laboratory, Department of Botany, University of Lucknow, Lucknow 226007, India \\ Correspondence should be addressed to Neelam Chandra; death2eternity@gmail.com
}

Received 25 March 2014; Accepted 4 August 2014; Published 29 October 2014

Academic Editor: Joël R. Drevet

Copyright (C) 2014 N. Chandra and N. Pandey. This is an open access article distributed under the Creative Commons Attribution License, which permits unrestricted use, distribution, and reproduction in any medium, provided the original work is properly cited.

\begin{abstract}
A pot culture experiment was carried out to assess the effect of sulfur stress on growth, oxidative status, and antioxidative metabolism. Onion plants were treated with three different levels of sulfur, namely, 1.0, 4.0, and $8.0 \mathrm{mM} \mathrm{L} \mathrm{L}^{-1}$. Plants raised with $4.0 \mathrm{mM} \mathrm{S} \mathrm{L}^{-1}$ represent sufficient growth for the best vegetative yield. Plants supplied with 1.0 and $8.0 \mathrm{mM} \mathrm{S} \mathrm{L}^{-1}$ showed retarded growth, chlorosis, and reduction in biomass and photoassimilatory pigments. Tissue sulfur concentration and cysteine were increased with increasing sulfur supply. Carbohydrates (sugars and starch) were accumulated in sulfur stressed plants. Hydrogen peroxide levels were increased in sulfur stressed plants. Thiobarbituric acid reactive substances levels were also increased which was an indicator of lipid peroxidation. Enzymatic (superoxide dismutase, catalase, peroxidase, ascorbate peroxidase, and glutathione reductase) and nonenzymatic (asorbate) antioxidative components were enhanced in sulfur stressed plants. Glutathione was increased with increasing sulfur supply. The present study showed that the adverse effects of inadequate sulfur supply result in irregular metabolic activities and antioxidant machinery.
\end{abstract}

\section{Introduction}

Recent studies have demonstrated that sulfur is important for the proper growth, metabolic activities, and development of plants. Sulfur is one of the most essential macronutrients required by the plants as it is an important constituent of amino acids such as cysteine and methionine and also in many metabolites [1].

Cysteine, as the first organic reduced sulfur compound, and methionine and its derivatives contribute to life not only as building blocks in proteins and their activity, but also as precursors for the synthesis of glutathione (GSH), cofactors (like Fe-S clusters, heme, siroheme, molybdenum centres, and lipoic acid), essential vitamins (biotin and thiamine), sulfur esters (coenzyme A), and sulfur derivatives. Sulfur is also an important constituent of several coenzymes, thioredoxins, and sulpholipids. Sulfur is also an important constituent of some compounds with may be involved in defense mechanisms against herbivores, pests, and pathogens or constituents to the special taste and odour of food plants [2]. Glutathione is a major thiol containing metabolite often present in millimolar concentrations and also associated with the defense system.

Sulfur is available primarily in the form of anionic sulfate $\left(\mathrm{SO}_{4}{ }^{2-}\right)$ to plants which is transported through roots and then distributed via xylem to stem and other parts of plants [1]. Visible symptoms of sulfur deficiency such as chlorosis appear first in young leaves while older leaves remain green, suggesting that sulfur is immobile in older leaves. Insoluble sulfur deficient conditions [3]. Sulfur deficiency also affects $\mathrm{CO}_{2}$ assimilation rates and rubisco enzyme activities and protein abundance [4].

Reactive oxygen species (ROS) are generally produced during cellular metabolism and cells are always ready to cope up with this condition through their antioxidative machinery and scavenging enzymes. Nutrient deficiencies are also responsible for ROS production [5-7]. Chloroplast is an important source of producing ROS like superoxide $\left(\mathrm{O}_{2}{ }^{-}\right)$and hydrogen peroxide $\left(\mathrm{H}_{2} \mathrm{O}_{2}\right)$ during reduced rate of photosynthetic carbon fixation [8]. Chloroplast can also produce ROS like singlet oxygen $\left({ }^{1} \mathrm{O}_{2}\right)$ through excited chlorophyll molecule [9]. Mitochondria and peroxisomes are 
also responsible for ROS production. In addition to these, ROS like hydroxyl radical $\left(\mathrm{OH}^{*}\right)$ can be formed from $\mathrm{H}_{2} \mathrm{O}_{2}$ and $\mathrm{O}_{2}{ }^{\bullet}$ through Haber-Weiss reaction [6].

The antioxidative machinery protects plants against this oxidative stress damage caused by ROS. Plants possess enzymatic (superoxide dismutase, catalase, peroxidise, ascorbate peroxidise, and glutathione reductase) and nonenzymatic (ascorbic acid and glutathione) components which work to protect the plant cells from oxidative damage by scavenging ROS [10]. So we have conducted this experiment in onion leaves, as sulfur has a very special role in onion plants, to evaluate changes in physiological and biochemical metabolism under induced sulfur stress. Sulfur has a marked effect on the pungency of the onion through increasing the pyruvic acid. The S-alkyl cysteine sulfoxides of the Alliaceae family contribute to the flavor and cancer prevention effects and generate S-containing volatile compounds upon tissue disruption and exposure to specific hydrolyzing enzymes [11]. When Allium species are grown with added sulfur, the increase in status of the plant correlates to an increase in the pungency [12]. When onion plants grown in the field were fertilized with sulfur, their S-propyl cysteine sulfoxides and Smethyl cysteine sulfoxide levels were more than double those of fertilized plants [13]. The level of S-alkyl cysteine sulfoxides is also dependent on sulfur nutrition [14].

\section{Materials and Methods}

Seeds of onion (Allium cepa L. var. Nasik-53) were sown in pots filled with purified and sterilized moist sand. Prior to sowing, the seeds were surface-sterilized with $5 \%(\mathrm{v} / \mathrm{v})$ mercuric chloride solution and then with distilled water. The plants were treated with nutrient medium containing$4 \mathrm{mM} \mathrm{KNO}_{3}, 4 \mathrm{mM} \mathrm{Ca}\left(\mathrm{NO}_{3}\right)_{2}, 1.33 \mathrm{mM} \mathrm{NaH}_{2} \mathrm{PO}_{4}, 0.33 \mu \mathrm{M}$ $\mathrm{HBO}_{3} 0.1 \mathrm{mM}$ Fe EDTA, $10 \mu \mathrm{M} \mathrm{MnSO}, 1 \mu \mathrm{M} \mathrm{CuSO}_{4}, 1 \mu \mathrm{M}$ $\mathrm{ZnSO}_{4}, 0.1 \mu \mathrm{M} \mathrm{Na}_{2} \mathrm{MoO}_{4}, 0.1 \mu \mathrm{M} \mathrm{NaCl}, 0.1 \mu \mathrm{M} \mathrm{CoSO}_{4}$, and $0.1 \mu \mathrm{M} \mathrm{NiSO}{ }_{4}$ [15]. Sulfur was supplied as $\mathrm{MgSO}_{4}$ and $\mathrm{Na}_{2} \mathrm{SO}_{4}$ at different levels. Sulfur was supplied as $\mathrm{Na}_{2} \mathrm{SO}_{4}$ and magnesium chloride is used for the compensation of magnesium in sulfur deficient plants. In sulfur excess plants, excess sulfur was supplied as $\mathrm{Na}_{2} \mathrm{SO}_{4}$. The experiment was conducted in randomized complete design with four replicates, and during the period in which the experiment was conducted, light intensity ranged between 605 to $745 \mu \mathrm{mol} \mathrm{m}^{-2} \mathrm{~s}^{-1}$ at noon. The temperature was ranged between $8-15^{\circ} \mathrm{C}$ and $17-38^{\circ} \mathrm{C}$, and relative humidity ranged between 87 to $94 \%$ at 9:30 a.m. in glass house. The effects of three different sulfur applications $\left(1.0,0.4\right.$, and $\left.8.0 \mathrm{mM} \mathrm{S} \mathrm{L}^{-1}\right)$ on growth, biomass, tissue sulfur, photoassmilatory pigments, cysteine, carbohydrates (sugars and starch), and antioxidative enzymatic and nonenzymatic components were evaluated, and the whole experiment was analysed at two stages 35 and 58 days of after treatment.

The plant material (leaves) was thoroughly cleaned by washing with tap water and then with deionzed water to remove surface contamination. After drying the fresh plant material in a forced drought oven at $70^{\circ} \mathrm{C}$ for 48 hours it was transferred to a desiccator and, when cool, was weighed accurately for the evaluation of biomass. Plant material (leaves) was wet-digested in nitric acid $\left(\mathrm{HNO}_{3}\right)$ and perchloric acid $\left(\mathrm{HClO}_{4}\right)$ which was in the ratio of $10: 1(\mathrm{~V} / \mathrm{V})$. After this, sulfur was evaluated turbidimetrically by the method of Chesnin and Yien [16]. Optical density was read within half an hour of the reaction at $430 \mathrm{~nm}$ on spectrophotometer.

For the estimation of photoassimilatory pigments, chopped leaves were ground in pestle mortar and extracted in $80 \%$ acetone with a pinch of calcium carbonate. Spectrophotometric measurements were made at 480 and $510 \mathrm{~nm}$ for carotenoids and 645 and $663 \mathrm{~nm}$ for chlorophylls [17]. To estimate sugar and starch in leaves, chopped leaves was fixed in boiling $80 \%$ ethanol. Sugars (reducing sugar and total sugar) were estimated colorimetrically by the method of Nelson [18] at $500 \mathrm{~nm}$. Starch was estimated by the method of Montgomary [19]. Cysteine concentration was determined by the method of Gaitonde [20]. Fresh plant material (leaves) was homogenized in $5 \%$ chilled perchloric acid. Reaction mixture contained suitable amount of extract, glacial acetic acid, and ninhydrin reagent. Colour developed was read at $560 \mathrm{~nm}$.

Hydrogen peroxide $\left(\mathrm{H}_{2} \mathrm{O}_{2}\right)$ was estimated by the method of Brennan and Frenkel [21]. Thiobarbituric acid reactive substances (TBARS) were estimated by the method of Heath and Packer [22]. The absorbance was read at $532 \mathrm{~nm}$ and adjusted for nonspecific absorbance at $600 \mathrm{~nm}$. The concentration of TBARS was estimated by using the extinction coefficient of $155 \mathrm{mM}^{-1} \mathrm{~cm}^{-1}$. Ascorbate was determined according to the method of Law et al. [23] by extracting fresh leaf tissue in $10 \%$ TCA. The color was developed by $10 \%$ TCA, $44 \%$ orthophosphoric acid, $4 \%$ bipyridyl in 70\% ethanol, and 3\% ferric chloride and read at $525 \mathrm{~nm}$. Glutathione was estimated by method of Ellman [24]. The reaction was carried out with the use of $10 \mathrm{mM}$ DTNB and $0.1 \mathrm{mM}$ GSH (glutathione reduced). The color intensity of extract was read out at $412 \mathrm{~nm}$.

The activity of superoxide dismutase (SOD) was determined by measuring the ability to inhibit the photochemical reduction of nitro-blue tetrazolium (NBT). The reaction mixture contained $50 \mathrm{mM}$ phosphate buffer $\mathrm{pH} 7.8,13 \mathrm{mM}$ methionine, $75 \mu \mathrm{M} \mathrm{NBT}, 2 \mu \mathrm{M}$ riboflavin, $0.1 \mathrm{mM}$ EDTA, and 0 to $50 \mu \mathrm{L}$ enzyme extract. Riboflavin was added at last and tubes were illuminated in sunlight for $10 \mathrm{~min}$. Color density was read out at $560 \mathrm{~nm}$. One unit of SOD represents the amount that inhibits the NBT reduction (Beauchamp and Fridovich) [25]. Catalase was assayed by the permagnate titration method of Euler and Josephson [26]. The enzyme assay was allowed to stand for 5 minutes at $25^{\circ} \mathrm{C}$. The reaction mixture for enzyme assay contained $0.005 \mathrm{M}$ hydrogen peroxide in $0.025 \mathrm{mM}$ potassium phosphate buffer $\mathrm{pH}$ 7.0. The reaction was stopped by adding $2 \mathrm{~N} \mathrm{H}_{2} \mathrm{SO}_{4}$. After stopping the reaction, titration was carried out. Peroxidase was assayed by the modified method of Luck [27]. The enzyme assay was carried out at $25^{\circ} \mathrm{C}$ in a solution containing $0.1 \mathrm{M}$ phosphate buffer $\mathrm{pH} 6.0,0.01 \% \mathrm{H}_{2} \mathrm{O}_{2}$, and $0.5 \% \mathrm{p}$-phenyl diamine. The reaction was initiated by adding enzyme extract to the above and was allowed to proceed for 5 minutes. The reaction was stopped by adding $4 \mathrm{~N} \mathrm{H}_{2} \mathrm{SO}_{4}$. The color intensity was read at $485 \mathrm{~nm}$. 
TABLE 1: Effect of variable sulfur supply on plant height, biomass and tissue sulfur concentration in leaves of onion plants (Allium cepa L. var. Nasik-53) at 35 and 58 days after treatment.

\begin{tabular}{|c|c|c|c|c|}
\hline \multirow{2}{*}{ Days after treatment } & \multirow{2}{*}{ Plant parts } & \multicolumn{3}{|c|}{$\mathrm{mM} \mathrm{S} \mathrm{L}^{-1}$ supply } \\
\hline & & 1.0 & 4.0 & 8.0 \\
\hline \multicolumn{5}{|c|}{ Plant height: $\mathrm{cm}$} \\
\hline 35 & & $15.89 \pm 1.101^{\mathrm{b}}$ & $18.33 \pm 1.208^{\mathrm{a}}$ & $13.24 \pm 1.015^{\mathrm{b}}$ \\
\hline 58 & & $26.37 \pm 2.203^{\mathrm{b}}$ & $30.75 \pm 2.031^{\mathrm{a}}$ & $26.89 \pm 2.011^{\mathrm{b}}$ \\
\hline \multicolumn{5}{|c|}{ Biomass: g plant ${ }^{-1}$} \\
\hline 35 & Leaves & $0.072 \pm 0.008^{\mathrm{b}}$ & $0.089 \pm 0.004^{\mathrm{a}}$ & $0.064 \pm 0.004^{\mathrm{b}}$ \\
\hline 58 & Leaves & $0.137 \pm 0.011^{\mathrm{b}}$ & $0.153 \pm 0.013^{\mathrm{a}}$ & $0.116 \pm 0.018^{\mathrm{c}}$ \\
\hline \multicolumn{5}{|c|}{ Sulfur: \% dry weight } \\
\hline 35 & Leaves & $0.104 \pm 0.012^{\mathrm{a}}$ & $0.212 \pm 0.010^{\mathrm{b}}$ & $0.378 \pm 0.015^{\mathrm{c}}$ \\
\hline 58 & Leaves & $0.232 \pm 0.026^{\mathrm{a}}$ & $0.442 \pm 0.029^{b}$ & $0.502 \pm 0.038^{c}$ \\
\hline
\end{tabular}

Values are mean $\pm \mathrm{SE}, n=4$. Data with different superscript letters in the same row indicate a significant difference at $P \leq 0.05$.

Activity of ascorbate peroxidase (APX) was determined as per the method of Nakano and Asada [28]. The reaction mixture consists of $50 \mathrm{mM}$ potassium phosphate buffer $\mathrm{pH}$ 7.0, $0.5 \mathrm{mM}$ ascorbate, and $0.1 \mathrm{mM}$ hydrogen peroxide. Optical density was read out at $290 \mathrm{~nm}$. The amount of ascorbate oxidized was calculated by using the extinction coefficient of $2.8 \mathrm{mM}^{-1} \mathrm{~cm}^{-1}$. Activity of glutathione reductase (GR) was evaluated by making a reaction mixture containing $100 \mathrm{mM}$ phosphate buffer $\mathrm{pH}$ 7.0, $1 \mathrm{mM}$ GSSG, $1 \mathrm{mM}$ EDTA, $0.1 \mathrm{mM}$ $\mathrm{NADPH}$, and 25 to $50 \mu \mathrm{L}$ of the enzyme extract. The optical density was read out at $340 \mathrm{~nm}$, and the amount of NADPH oxidized was calculated using the extinction coefficient of $6.22 \mathrm{mM}^{-1} \mathrm{~cm}^{-1}$ [29].

Statistical Analysis. The data has been presented in tables and figures and statistically evaluated by ANOVA. Differences between treatments means were compared using least significant differences [LSD at $P \leq 0.05]$ and as mean values standard error $( \pm$ SE).

\section{Result and Discussion}

3.1. Plant Height, Growth, and Visible Morphology. Onion plants supplied with $1.0 \mathrm{mM} \mathrm{S} \mathrm{L}^{-1}$ and $8.0 \mathrm{mM} \mathrm{S} \mathrm{L}^{-1}$ showed an inhibition in growth leading to significant reductions in plant height [30] to the plant grown at $4.0 \mathrm{mM} \mathrm{S} \mathrm{L}^{-1}$ which showed best vegetative growth and was treated as normal plants (Table 1). Highest reduction in plant height was observed in plants supplied with $8 \mathrm{mM} \mathrm{S} \mathrm{L}^{-1}$ at $35 \mathrm{DAT}$; while at $58 \mathrm{DAT}$, there is not any difference in plant height of both Sdeficient and S-excess plants. Plant growth was also reduced in sulfur deficient and excess plants. The deficiency symptoms of sulfur first appeared in young leaves. These were chlorosis and reduction in size of leaves. A mild chlorosis was observed at $20 \mathrm{DAT}$ at the apex of leaves [30-32]. After 35 days chlorosis was spreading from apex to base of the leaves. At 35 days, tip burning was also observed in leaves of sulfur deficient and excess plants. Sulfur deficiency was also responsible for curling in leaves at later stage.
3.2. Biomass, Tissue S Concentration, and Cysteine. Biomass was reduced in sulfur stressed plants and reduction was more prominent in S-excess plants. Tissue $S$ concentration and cysteine were increasing with increasing $S$ supply from 1.0 to $8.0 \mathrm{mM} \mathrm{S} \mathrm{L}^{-1}$ (Table 1) which is in consonance with the results of Chandra and Pandey [30, 32]. It is generally well known that the uptake and assimilation of sulfate is induced under conditions of sulfur starvation or high demand, for sulfur metabolites. Sulfate is incorporated into the soluble fraction of leaves which are about $70 \%$ expanded and most of this sulfur is redirected into new expanding leaves $[33,34]$. Sulfur stress does not increase the export of sulfur from mature leaves to Young leaves as reported earlier by Adiputra and Anderson [35]. Export of sulfur from the leaves of sulfur deficient plants was restricted to the export of sulfur from the soluble fraction, as in normal plants. In S-deficient plants, young recipient leaves incorporate less sulfur from the soluble fraction into the soluble fraction. Due to these reasons, sulfur deficiency symptoms occur in youngest leaves of S-deficient plants [36].

Transportation of sulfur in plants is carried out by a complex system of transporters encoded by a large gene family [37]. In leaves, AtSultr 2:1 is expressed in the xylem parenchyma and phloem cells; but in the root it is expressed in xylem parenchyma and pericycle cells. In leaves, a considerable diversity of patterns of expression may be visualized during development and in response to fluctuating sulfur availability. Group 3 consists of 5 sulfate transporters (AtSultr $3: 1,3: 2,3: 3,3: 4$, and $3: 5$ ) and are known as leaf expressed group [38]. Formation of cysteine was directly related to $S$ concentration as it contains $S$. Cysteine plays a very important role in plant metabolism as it regulates glutathione synthesis. Cysteine also functions as a sulfur donor for methionine and secondary metabolites biosynthesis [1]. Cysteine in the low molecular weight glutathione (GSH) and derivatives (phytochelatin polymers) also plays a critical role in production against abiotic/biotic stress [39, 40]. Sulfur starvation is responsible for the increase of OAS (O-acetyl serine) levels, which in turn induces the expression of genes encoding sulfate transporters and APS reductase, thereby overriding 
TABLE 2: Effect of variable sulfur supply on photoassimilatory pigments (chlorophyll a and b and total chlorophyll and carotenoid) in leaves of onion (Allium cepa L. var. Nasik-53) plants at 35 and 58 days after treatment.

\begin{tabular}{|c|c|c|c|c|}
\hline \multirow{2}{*}{ Days after treatment } & & \multicolumn{3}{|c|}{$\mathrm{mMS} \mathrm{L}^{-1}$ supply } \\
\hline & & 1.0 & 4.0 & 8.0 \\
\hline \multicolumn{5}{|c|}{ Chlorophyll: $\mathrm{mg} \mathrm{g}^{-1}$ fresh weight } \\
\hline \multirow{4}{*}{35} & Chl a & $0.432 \pm 0.013^{\mathrm{a}}$ & $0.803 \pm 0.017^{\mathrm{c}}$ & $0.522 \pm 0.019^{\mathrm{b}}$ \\
\hline & Chl b & $0.211 \pm 0.024^{\mathrm{b}}$ & $0.447 \pm 0.018^{\mathrm{a}}$ & $0.242 \pm 0.027^{\mathrm{b}}$ \\
\hline & Total chl & $0.643 \pm 0.031^{\mathrm{a}}$ & $1.250 \pm 0.044^{\mathrm{b}}$ & $0.764 \pm 0.053^{\mathrm{c}}$ \\
\hline & $\mathrm{Chl} \mathrm{a/b}$ & $2.047 \pm 0.151^{\mathrm{a}}$ & $1.796 \pm 0.160^{\mathrm{b}}$ & $2.157 \pm 0.158^{\mathrm{c}}$ \\
\hline \multirow{4}{*}{58} & Chl a & $0.209 \pm 0.011^{\mathrm{a}}$ & $0.615 \pm 0.021^{c}$ & $0.331 \pm 0.016^{\mathrm{b}}$ \\
\hline & Chl b & $0.167 \pm 0.014^{\mathrm{a}}$ & $0.376 \pm 0.023^{\mathrm{c}}$ & $0.190 \pm 0.022^{b}$ \\
\hline & Total chl & $0.376 \pm 0.034^{\mathrm{a}}$ & $0.991 \pm 0.039^{c}$ & $0.521 \pm 0.047^{\mathrm{b}}$ \\
\hline & $\mathrm{Chl} \mathrm{a/b}$ & $1.251 \pm 0.103^{\mathrm{a}}$ & $1.635 \pm 0.118^{\mathrm{b}}$ & $1.742 \pm 0.112^{\mathrm{c}}$ \\
\hline \multirow{3}{*}{35} & & oids: $\mathrm{mg} \mathrm{g}^{-1}$ fres & & \\
\hline & Car & $0.362 \pm 0.012^{\mathrm{b}}$ & $0.482 \pm 0.014^{\mathrm{a}}$ & $0.397 \pm 0.015^{\mathrm{c}}$ \\
\hline & $\mathrm{Chl} / \mathrm{car}$ & $1.776 \pm 0.178^{\mathrm{b}}$ & $2.593 \pm 0.172^{\mathrm{a}}$ & $1.924 \pm 0.168^{\mathrm{b}}$ \\
\hline \multirow{2}{*}{58} & Car & $0.211 \pm 0.017^{\mathrm{a}}$ & $0.374 \pm 0.016^{\mathrm{c}}$ & $0.230 \pm 0.021^{\mathrm{b}}$ \\
\hline & $\mathrm{Chl} / \mathrm{car}$ & $1.781 \pm 0.163^{\mathrm{a}}$ & $2.649 \pm 0.182^{b}$ & $2.265 \pm 0.160^{\mathrm{c}}$ \\
\hline
\end{tabular}

Values are mean \pm SE, $n=4$. Data with different superscript letters in the same row indicate a significant difference at $P \leq 0.05$.

TABLE 3: Effect of variable sulfur supply on carbohydrates (reducing sugar, nonreducing sugar, and total sugar and starch) and cysteine concentration in leaves of onion plants (Allium cepa L. var. Nasik-53) at 35 and 58 days after treatment.

\begin{tabular}{|c|c|c|c|c|}
\hline \multirow{2}{*}{ Days after treatment } & & \multicolumn{3}{|c|}{ mM S L ${ }^{-1}$ supply } \\
\hline & & 1.0 & 4.0 & 8.0 \\
\hline \multicolumn{5}{|c|}{ Carbohydrates: \% fresh weight } \\
\hline \multirow{5}{*}{35} & Reducing sugar & $0.189 \pm 0.013^{\mathrm{b}}$ & $0.073 \pm 0.017^{\mathrm{a}}$ & $0.151 \pm 0.012^{c}$ \\
\hline & Nonreducing sugar & $0.040 \pm 0.022^{\mathrm{a}}$ & $0.053 \pm 0.013^{\mathrm{b}}$ & $0.067 \pm 0.024^{\mathrm{c}}$ \\
\hline & Total sugar & $0.229 \pm 0.027^{\mathrm{b}}$ & $0.126 \pm 0.030^{\mathrm{a}}$ & $0.218 \pm 0.031^{\mathrm{b}}$ \\
\hline & Starch & $0.913 \pm 0.162^{\mathrm{c}}$ & $0.704 \pm 0.143^{\mathrm{a}}$ & $0.822 \pm 0.137^{\mathrm{b}}$ \\
\hline & Reducing sugar & $0.252 \pm 0.019^{\mathrm{b}}$ & $0.130 \pm 0.014^{\mathrm{a}}$ & $0.276 \pm 0.013^{\mathrm{b}}$ \\
\hline \multirow{3}{*}{58} & Nonreducing sugar & $0.651 \pm 0.031^{c}$ & $0.102 \pm 0.027^{\mathrm{a}}$ & $0.577 \pm 0.021^{\mathrm{b}}$ \\
\hline & Total sugar & $0.903 \pm 0.024^{\mathrm{b}}$ & $0.232 \pm 0.032^{\mathrm{a}}$ & $0.853 \pm 0.029^{b}$ \\
\hline & Starch & $1.115 \pm 0.124^{\mathrm{c}}$ & $0.775 \pm 0.136^{\mathrm{a}}$ & $0.900 \pm 0.147^{\mathrm{b}}$ \\
\hline \multicolumn{5}{|c|}{ Cysteine: $\mathrm{mM} 100 \mathrm{mg}^{-1}$} \\
\hline 35 & Cysteine & $0.164 \pm 0.004^{\mathrm{a}}$ & $0.183 \pm 0.003^{\mathrm{b}}$ & $0.227 \pm 0.006^{\mathrm{c}}$ \\
\hline 58 & Cysteine & $0.122 \pm 0.008^{\mathrm{a}}$ & $0.166 \pm 0.006^{\mathrm{b}}$ & $0.187 \pm 0.004^{c}$ \\
\hline
\end{tabular}

Values are mean $\pm \mathrm{SE}, n=4$. Data with different superscript letters in the same row indicate a significant difference at $P \leq 0.05$.

the repressive effect of sulfur-sufficient nutritional conditions [41]. OAS (thiol-) lyase, catalyzing the reaction of formation of cysteine from OAS and hydrogen sulfide, is in the same subcellular compartments as serine acetyltransferase. OAS accumulation stimulated by S-deficiency further promotes the dissociation of the complex to reduce the activity of ser acetyltransferase, resulting in reduced OAS formation. In turn, upon excess sulfur supply, accumulated sulfide promotes formation of the complex leading to stimulated OAS formation to maintain cysteine synthesis [42].

3.3. Photoassimilatory Pigments. Chlorophyll (chl a and chl b) and carotenoid (car) reduced in S-stressed plants, and reduction was found to be more significant in S-deficient plants in comparison to S-excess plants. Highest reduction in chlorophyll ( $\mathrm{a}$ and $\mathrm{b}$ ) concentration was observed under Sdeficiency. In comparison to $35 \mathrm{DAT}$, chl a, chl b, and car were reduced more at $58 \mathrm{DAT}$ in S-stressed plants which shows that severe deficiency results in reduced chlorophyll (Table 2).
Reduction in chlorophyll concentration was also observed by Lunde et al. [43], Brennan et al. [31], and Tewari et al. [44] in rice, canola, and mulberry, respectively. At $35 \mathrm{DAT}$ ratio of chl $\mathrm{a}$ and $\mathrm{b}$ was increased while at 58 DAT it was increased with increasing sulfur supply. Carotenoid concentration was decreased more at 58 DAT in comparison to 35 DAT in Sstressed onion plants. The ratio of chlorophyll and carotenoid was decreased under sulfur stressed plants in comparison to normal plants (Table 2).

3.4. Carbohydrates. Sulfur concentration also alters carbohydrates concentration in the leaves of onion plants. Sugars and starch both were accumulated in S-stressed plants. Reducing sugar accumulated more in S-deficient plants while nonreducing sugar was higher in S-excess plants. Total sugar was accumulated in sulfur stressed plants and more prominent in leaves of S-deficient plants and especially at 58 DAT. Starch also showed same trend as total sugar (Table 3). Starch 

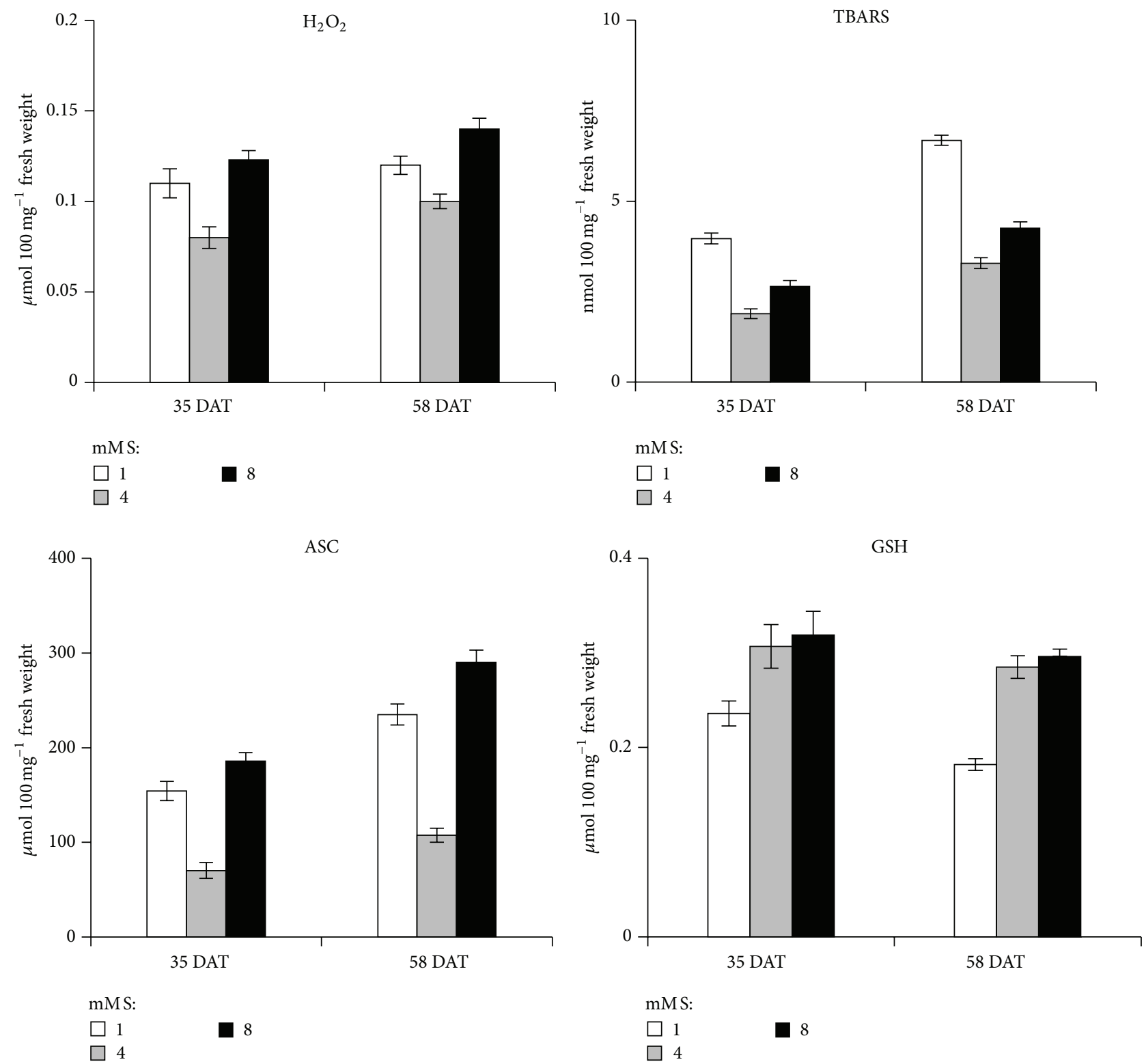

FIGURE 1: Effect of sulfur supply on hydrogen peroxide $\left(\mathrm{H}_{2} \mathrm{O}_{2}\right)$, thiobarbutric acid reactive substances (TBARS), ascorbate (ASC), and glutathione $(\mathrm{GSH})$ in leaves of onion (Allium cepa L. var. Nasik-53) plants (levels $\mathrm{mMS} \mathrm{L}^{-1}: 1.0$, 4.0, and 8.0). Data represent mean \pm S.E. $(P \leq 0.05)$.

accumulation under sulfur deficiency was also observed by Lunde et al. [43].

Reduced chlorophyll and decreased rubisco concentration was observed under sulfur deficiency [45]. Starch accumulation in S-deficient plants was better described on the basis of Fd:thioredoxin system [46, 47]. Carbohydrate concentration is directly dependent on photosynthetic process. Photosynthesis is essentially a redox process and it makes substantial use of sulfur. Sulfur atoms are located in compartments of the electron transfer chain and in carriers of reducing power generated by the photosynthetic electron transfer (e.g., ferredoxin). Disulfide bridges also play an important role in carbohydrate metabolism as they are involved in light/dark regulation of Calvin cycle enzymes [48]. There are few reports that excess $S$ in form of sulfate is responsible for carbohydrate accumulation. But excess sulfur in form of $\mathrm{SO}_{2}$ was responsible for the accumulation of carbohydrate [49].

3.5. $\mathrm{H}_{2} \mathrm{O}_{2}, T B A R S, A S C$, and GSH. Increased accumulation of ROS in plant tissues is an oxidative common condition in stressed plants. Under stress, plants redox equilibrium is altered and ROS accumulation causes specific oxidative stress. Compared with the control plants, S-deficient and excess conditions significantly increased the concentration of $\mathrm{H}_{2} \mathrm{O}_{2}$ (Figure 1). Increment in $\mathrm{H}_{2} \mathrm{O}_{2}$ due to sulfur deficiency 

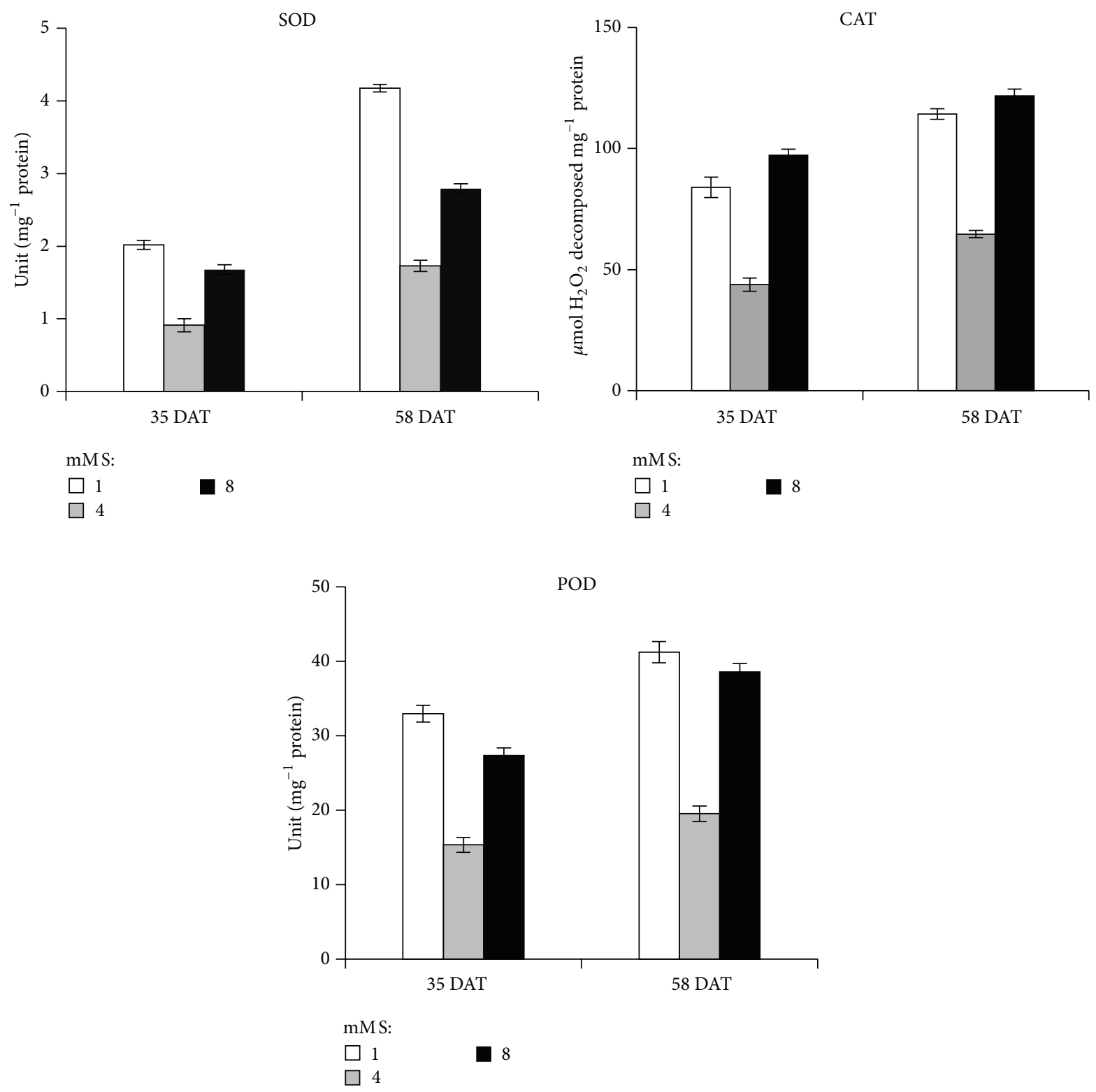

Figure 2: Effect of sulfur supply on superoxide dismutase (SOD), catalase (CAT), and peroxidase (POD) in leaves of onion (Allium cepa L. var. Nasik-53) plants (levels $\mathrm{mM} \mathrm{S} \mathrm{L}^{-1}: 1.0,4.0$, and 8.0). Data represent mean \pm S.E. $(P \leq 0.05)$.

was reported by Tewari et al. $[44,50]$ in mulberry and maize respectively. At $35 \mathrm{DAT}, \mathrm{H}_{2} \mathrm{O}_{2}$ concentration was increased up to $38 \%$ and $54 \%$ in 1 and $8 \mathrm{mM} \mathrm{S} \mathrm{L}^{-1}$ by normal plants. But at $58 \mathrm{DAT}, \mathrm{H}_{2} \mathrm{O}_{2}$ concentrations were increased as $23 \%$ and $40 \%$ in 1 and $8 \mathrm{mM} \mathrm{S} \mathrm{L}^{-1}$ as compared to normal plants. This shows that antioxidants were trying to remove the excess of $\mathrm{H}_{2} \mathrm{O}_{2}$ molecule and minimizing the oxidative damage. Excess $\mathrm{H}_{2} \mathrm{O}_{2}$ can be transferred via the Haber-Weiss reaction to form highly reactive oxidant $\mathrm{OH}$ which leads to the lipid peroxidation. In the present study, concentration of TBARS which was found to be increased in stressed plants often indicates severe lipid peroxidation. Concentration of TBARS showed a significant increase at 58 DAT which shows severe stressed condition (Figure 1). Percentage increase was found to be highest (110\%) at 35 DAT in plants supplied with $1 \mathrm{mM} \mathrm{s} \mathrm{L}^{-1}$. The present investigation revealed that the concentration of ascorbate was increased in both S-deficient and S-excess supplied plants in comparison to normal plants (Figure 1). Concentration of glutathione was increased with increasing sulfur supply. Our results were in consonance with the reports of Chandra and Pandey [32]. Ascorbate concentration was more at $8 \mathrm{mM} \mathrm{S} \mathrm{L}^{-1}$ in comparison to $1 \mathrm{mM} \mathrm{S} \mathrm{L}^{-1}$. At $58 \mathrm{DAT}$, percentage increase $(171 \%)$ was the highest at $8 \mathrm{mMS} \mathrm{L}^{-1}$. Ascorbate is the powerful antioxidant which helps the plant metabolism to minimizing the damage caused by different reactive oxygen species. Chloroplast contains about 30 to $40 \%$ of total ascorbate [51] and, except for scavenging ROS, it has also a special role in preserving the activities of different 

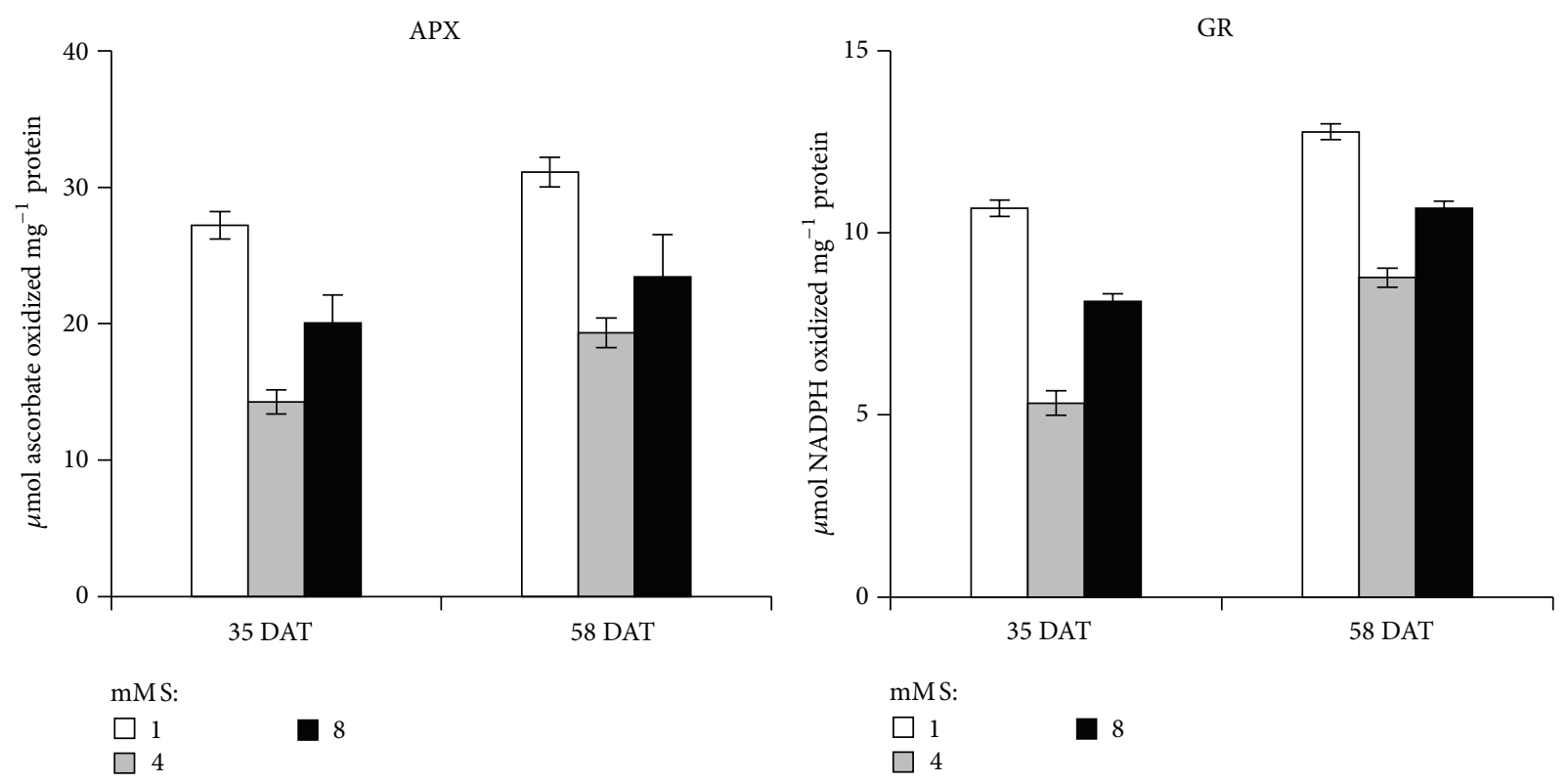

FIGURE 3: Effect of sulfur supply on ascorbate peroxidase (APX) and glutathione reductase (GR) in leaves of onion (Allium cepa L. var. Nasik-53) plants (levels $\mathrm{mM} \mathrm{S} \mathrm{L}^{-1}: 1.0,4.0$, and 8.0). Data represent mean \pm S.E. $(P \leq 0.05)$.

enzymes that contain prosthetic transition metal ions [52]. Glutathione is an important $\mathrm{S}$ containing metabolite found in plants which prevents ROS induced oxidative damage. It also plays an essential role in the regulation of sulphate transport, signal transduction, conjugation of different metabolite, and detoxification of xenobiotics [53]. Glutathione is also important to maintain reduced state of cells to counteract the inhibitory effects of oxidative stress [54]. Concentration of GSH is totally dependent upon the sulfate availability. In present experiment concentration of GSH was increased with increasing $S$ supply (Figure 1). Glutathione is also thought to be a phloem-translocated signal molecule that represses the genes of sulfur assimilation [55].

3.6. Antioxidative Enzymes. To cope with oxidative damage, plants have an efficient antioxidative mechanism. In this study, a significant increase in SOD activities in leaves was observed under sulfur deficiency which was in consonance with the reports of Tewari et al. $[44,50]$. The activity of SOD was also increased in S-excess plants. Superoxide dismutase activity was very high in S-deficient plants in comparison to S-excess plants at both stages (Figure 2). SOD activity increases to convert superoxide radical to $\mathrm{H}_{2} \mathrm{O}_{2}$ which is also a ROS and damage membrane. And plants will be completely protected when $\mathrm{H}_{2} \mathrm{O}_{2}$ is converted into water and oxygen. $\mathrm{H}_{2} \mathrm{O}_{2}$ is efficiently removed by catalase and peroxidase. Increased activity of CAT and POD was observed at both stages in leaves of onion plants which may remove excess $\mathrm{H}_{2} \mathrm{O}_{2}$ caused by $\mathrm{S}$-stress and thus play a detoxifying role. Percentage increase in activity was found to be more at 35 DAT in comparison to 58 DAT, while CAT activity was more at 58 DAT. Peroxidase activity was observed more at 58 DAT in comparison to plants analyzed at 35 DAT both under S-deficient and S-excess plants (Figure 2).
Activity of APX and GR was also found to be more at 58 DAT in comparison to 35 DAT (Figure 3). The highest activity of APX and GR was observed at $1 \mathrm{mMSL}^{-1}$ at 58 DAT. APX has a very special role in scavenging ROS through water-water and ASH-GSH cycles by utilizing ASH as the electron donor. And GR is an enzyme of ASH-GSH cycle. Glutathione reductase also detoxifies plant cells by scavenging ROS by sustaining the reduced status of GSH. It catalyzes the reduction of glutathione and also catalyzes the NADPH-dependent reaction of disulphide bond of GSSG [10].

In conclusion, onion leaves treated with low- and high-S induced a concentration-dependent oxidative stress characterized by accumulation of hydrogen peroxide with increased lipid peroxidation levels, increased superoxide dismutase, catalase, peroxidase, ascorbate peroxidise, and glutathione reductase displaying a better antioxidant response. Ascorbate was also increased, and glutathione was increased with increasing sulfur supply. Finally, current study identified the potential role of sulfur in metabolism of onion plants. Ascorbate was also increased and glutathione was increased with increasing sulfur supply. Finally, current study identified the potential role of sulfur in metabolism of onion plants.

\section{Conflict of Interests}

The authors declare that there is no conflict of interests regarding the publication of this paper.

\section{References}

[1] T. Leustek and K. Saito, "Sulfate transport and assimilation in plants," Plant Physiology, vol. 120, no. 3, pp. 637-643, 1999. 
[2] R. N. Bennett and R. M. Wallsgrove, "Transley Review No.72. Secondary metabolites in plant defence mechanisms," New Phytologist, vol. 127, no. 4, pp. 617-633, 1994.

[3] Sunarpi and J. W. Anderson, "Effect of sulfur nutrition on the redistribution of sulfur in vegetative soybean plants," Plant Physiology, vol. 112, no. 2, pp. 623-631, 1996.

[4] S. M. Gilbert, D. T. Clarkson, M. Cambridge, H. Lambers, and M. J. Hawkesford, " $\mathrm{SO}_{4}{ }^{2-}$ deprivation has an early effect on the content of ribulose-1,5-bisphosphate carboxylase/oxygenase and photosynthesis in young leaves of wheat," Plant Physiology, vol. 115, no. 3, pp. 1231-1239, 1997.

[5] R. Mittler, "Abiotic stress, the field environment and stress combination," Trends in Plant Science, vol. 11, no. 1, pp. 15-19, 2006.

[6] I. M. Møller, P. E. Jensen, and A. Hansson, "Oxidative modifications to cellular components in plants," Annual Review of Plant Biology, vol. 58, pp. 459-481, 2007.

[7] P. Jaspers and J. Kangasjärvi, "Reactive oxygen species in abiotic stress signaling," Physiologia Plantarum, vol. 138, no. 4, pp. 405413, 2010.

[8] S. Takahashi and N. Murata, "How do environmental stresses accelerate photoinhibition?” Trends in Plant Science, vol. 13, no. 4, pp. 178-182, 2008.

[9] C. Triantaphylidès and M. Havaux, "Singlet oxygen in plants: production, detoxification and signaling," Trends in Plant Science, vol. 14, no. 4, pp. 219-228, 2009.

[10] S. S. Gill and N. Tuteja, "Reactive oxygen species and antioxidant machinery in abiotic stress tolerance in crop plants," Plant Physiology and Biochemistry, vol. 48, no. 12, pp. 909-930, 2010.

[11] K. L. Falk, J. G. Tokuhisa, and J. Gershenzon, "The effect of sulfur nutrition on plant glucosinolate content: physiology and molecular mechanisms," Plant Biology, vol. 9, no. 5, pp. 573-581, 2007.

[12] E. Bloem, S. Haneklaus, and E. Schnug, "Influence of nitrogen and sulfur fertilization on the alliin content of onions and garlic," Journal of Plant Nutrition, vol. 27, no. 10, pp. 1827-1839, 2004.

[13] J. McCallum, N. Porter, B. Searle, M. Shaw, B. Bettjeman, and M. McManus, "Sulfur and nitrogen fertility affects flavour of fieldgrown onions," Plant and Soil, vol. 269, no. 1-2, pp. 151-158, 2005.

[14] D. E. Kopsell, D. A. Kopsell, W. M. Randle, T. W. Coolong, C. E. Sams, and J. Curran-Celentano, "Kale carotenoids remain stable while flavor compounds respond to changes in sulfur fertility," Journal of Agricultural and Food Chemistry, vol. 51, no. 18, pp. 5319-5325, 2003.

[15] C. P. Sharma, Micronutrient Project (ICAR) Bulletin No. 1, Lucknow University Centre, Lucknow, India, 1996.

[16] L. Chesnin and C. H. Yien, "Turbidimetric determination of available sulphates," Soil Science and Society of American Proceedings, vol. 15, pp. 149-151, 1951.

[17] H. K. Lichtenthaler, "Chlorophylls and carotenoids: pigments of photosynthetic biomembranes," in Methods in Enzymology, L. Packer and R. Douce, Eds., pp. 350-382, Academic Press, New York, NY, USA, 1987.

[18] N. Nelson, "Photometric adaptation of Somogyi's method for determination of glucose," The Journal of Biological Chemistry, vol. 53, pp. 375-378, 1944.

[19] R. Montgomery, "Determination of glycogen," Archives of Biochemistry and Biophysics, vol. 67, no. 2, pp. 378-386, 1957.

[20] M. K. Gaitonde, "A spectrophotometric method for the direct determination of cysteine in the presence of other naturally occurring amino acids," Biochemical Journal, vol. 104, no. 2, pp. 627-633, 1967.

[21] T. Brennan and C. Frenkel, "Involvement of hydrogen peroxide in the regulation of senescence in pear," Plant Physiology, vol. 59, no. 3, pp. 411-416, 1977.

[22] R. L. Heath and L. Packer, "Photoperoxidation in isolated chloroplasts. I. Kinetics and stoichiometry of fatty acid peroxidation," Archives of Biochemistry and Biophysics, vol. 125, no. 1, pp. 189-198, 1968.

[23] M. Y. Law, S. A. Charles, and B. Halliwell, "Glutathione and ascorbic acid in spinach (Spinacia oleracea) chloroplasts. The effect of hydrogen peroxide and of Paraquat," Biochemical Journal, vol. 210, no. 3, pp. 899-903, 1983.

[24] G. L. Ellman, "Tissue sulfhydryl groups," Archives of Biochemistry and Biophysics, vol. 82, no. 1, pp. 70-77, 1959.

[25] C. Beauchamp and I. Fridovich, "Superoxide dismutase: improved assays and an assay applicable to acrylamide gels," Analytical Biochemistry, vol. 44, no. 1, pp. 276-287, 1971.

[26] H. V. Euler and K. Josephson, "Uber katalase. I," Justus Liebigs Annalen der Chemie, vol. 452, no. 1, pp. 158-181, 1927.

[27] M. Luck, "Peroxidase," in Methods of Enzymic Analysis, H. V. Bergmeyer, Ed., pp. 895-897, Academic Press, New York, NY, USA, 1963.

[28] Y. Nakano and K. Asada, "Hydrogen peroxide is scavenged by ascorbate-specific peroxidase in spinach chloroplasts," Plant and Cell Physiology, vol. 22, no. 5, pp. 867-880, 1981.

[29] R. Mittler and B. A. Zilinskas, "Regulation of pea cytosolic ascorbate peroxidase and other antioxidant enzymes during the progression of drought stress and following recovery from drought," Plant Journal, vol. 5, no. 3, pp. 397-405, 1994.

[30] N. Chandra and N. Pandey, "Effect of sulfur on the growth, dry matter, tissue sulfur and carbohydrate concentration of Allium sativum L. and Allium cepa L,' Indian Journal of Agricultural Biochemistry, vol. 26, no. 2, pp. 182-186, 2013.

[31] R. F. Brennan, R. W. Bell, C. Raphael, and H. Eslick, "Sources of sulfur for dry matter, seed yield, and oil concentration of canola grown in sulfur deficient soils of south-western Australia," Journal of Plant Nutrition, vol. 33, no. 8, pp. 1180-1194, 2010.

[32] N. Chandra and N. Pandey, "Antioxidant status of Vigna mungo L. in response to sulfur nutrition," Chinese Journal of Biology, vol. 2014, Article ID 724523, 9 pages, 2014.

[33] C. I. Bell, D. T. Clarkson, and J. W. Cram, "Partitioning and redistribution of sulphur during S-stress in Macroptilium atropurpureum cv. Siratro," Journal of Experimental Botany, vol. 46, no. 282, pp. 73-81, 1995.

[34] J. W. Anderson, "Allocation of S in generative growth of soybean," Plant Physiology, vol. 114, no. 2, pp. 687-693, 1997.

[35] I. G. K. Adiputra and J. W. Anderson, "Effect of sulphur nutrition on redistribution of sulphur in vegetive barley," Physiologia Plantarum, vol. 95, no. 4, pp. 643-650, 1995.

[36] H. Marschner, Mineral Nutrition of Higher Plants, Academic Press, London, UK, 2nd edition, 1995.

[37] F. W. Smith, P. M. Ealing, M. J. Hawkesford, and D. T. Clarkson, "Plant members of a family of sulfate transporters reveal functional subtypes," Proceedings of the National Academy of Sciences of the United States of America, vol. 92, no. 20, pp. 93739377, 1995.

[38] M. J. Hawkesford, "Plant responses to sulphur deficiency and the genetic manipulation of sulphate transporters to improve S-utilization efficiency," Journal of Experimental Botany, vol. 51, no. 342, pp. 131-138, 2000. 
[39] T. Leustek, M. N. Martin, J. A. Bick, and J. P. Davies, "Pathways and regulation of sulfur metabolism revealed through molecular and genetic studies," Annual Review of Plant Physiology and Plant Molecular Biology, vol. 51, pp. 141-165, 2000.

[40] G. Noctor, A. M. Arisi, L. Jouanin, K. J. Kunert, H. Rennenberg, and C. H. Foyer, "Glutathione: biosynthesis, metabolism and relationship to stress tolerance explored in transformed plants," Journal of Experimental Botany, vol. 49, no. 321, pp. 623-647, 1998.

[41] A. Koprivova, M. Suter, R. Op den Camp, C. Brunold, and S. Kopriva, "Regulation of sulfate assimilation by nitrogen in Arabidopsis," Plant Physiology, vol. 122, no. 3, pp. 737-746, 2000.

[42] K. Saito, "Sulfur assimilatory metabolism: the long and smelling road," Plant Physiology, vol. 136, no. 1, pp. 2443-2450, 2004.

[43] C. Lunde, A. Zygadlo, H. T. Simonsen, P. L. Nielsen, A. Blennow, and A. Haldrup, "Sulfur starvation in rice: the effect on photosynthesis, carbohydrate metabolism, and oxidative stress protective pathways," Physiologia Plantarum, vol. 134, no. 3, pp. 508-521, 2008.

[44] R. K. Tewari, P. Kumar, and P. N. Sharma, "Morphology and oxidative physiology of sulphur-deficient mulberry plants," Environmental and Experimental Botany, vol. 68, no. 3, pp. 301308, 2010.

[45] R. M. B. Ferreira and A. R. N. Teixeira, "Sulfur starvation in Lemna leads to degradation of ribulose-bisphosphate carboxylase without plant death," The Journal of Biological Chemistry, vol. 267, no. 11, pp. 7253-7257, 1992.

[46] Y. Balmer, W. H. Vensel, N. Cai et al., "A complete ferredoxin/thioredoxin system regulates fundamental processes in amyloplasts," Proceedings of the National Academy of Sciences of the United States of America, vol. 103, no. 8, pp. 2988-2993, 2006.

[47] P. Geigenberger, A. Kolbe, and A. Tiessen, "Redox regulation of carbon storage and partitioning in response to light and sugars," Journal of Experimental Botany, vol. 56, no. 416, pp. 1469-1479, 2005.

[48] P. G. Falkowski and J. A. Raven, Aquatic Photosynthesis, Blackwell Science, Malden, Mass, USA, 1997.

[49] M. Farooq and R. K. Hans, "Metabolic effects of sulfur dioxide fumigation on Mangifera indica plants," Bulletin of Environmental Contamination and Toxicology, vol. 63, no. 6, pp. 774-781, 1999.

[50] R. K. Tewari, P. Kumar, N. Tewari, S. Srivastava, and P. N. Sharma, "Macronutrient deficiencies and differential antioxidant responses-influence on the activity and expression of superoxide dismutase in maize," Plant Science, vol. 166, no. 3, pp. 687-694, 2004.

[51] C. H. Foyer and G. Noctor, "Redox homeostasis and antioxidant signaling: a metabolic interface between stress perception and physiological responses," Plant Cell, vol. 17, no. 7, pp. 1866-1875, 2005.

[52] G. Noctor and C. H. Foyer, "Ascorbate and glutathione: keeping active oxygen under control," Annual Review of Plant Biology, vol. 49, pp. 249-279, 1998.

[53] C. Xiang, B. L. Werner, E. M. Christensen, and D. J. Oliver, "The biological functions of glutathione revisited in Arabidopsis transgenic plants with altered glutathione levels," Plant Physiology, vol. 126, no. 2, pp. 564-574, 2001.

[54] A. J. Meyer, "The integration of glutathione homeostasis and redox signaling," Journal of Plant Physiology, vol. 165, no. 13, pp. 1390-1403, 2008.
[55] A. G. Lappartient, J. J. Vidmar, T. Leustek, A. D. M. Glass, and B. Touraine, "Inter-organ signaling in plants: regulation of ATP sulfurylase and sulfate transporter genes expression in roots mediated by phloem-translocated compound," Plant Journal, vol. 18, no. 1, pp. 89-95, 1999. 

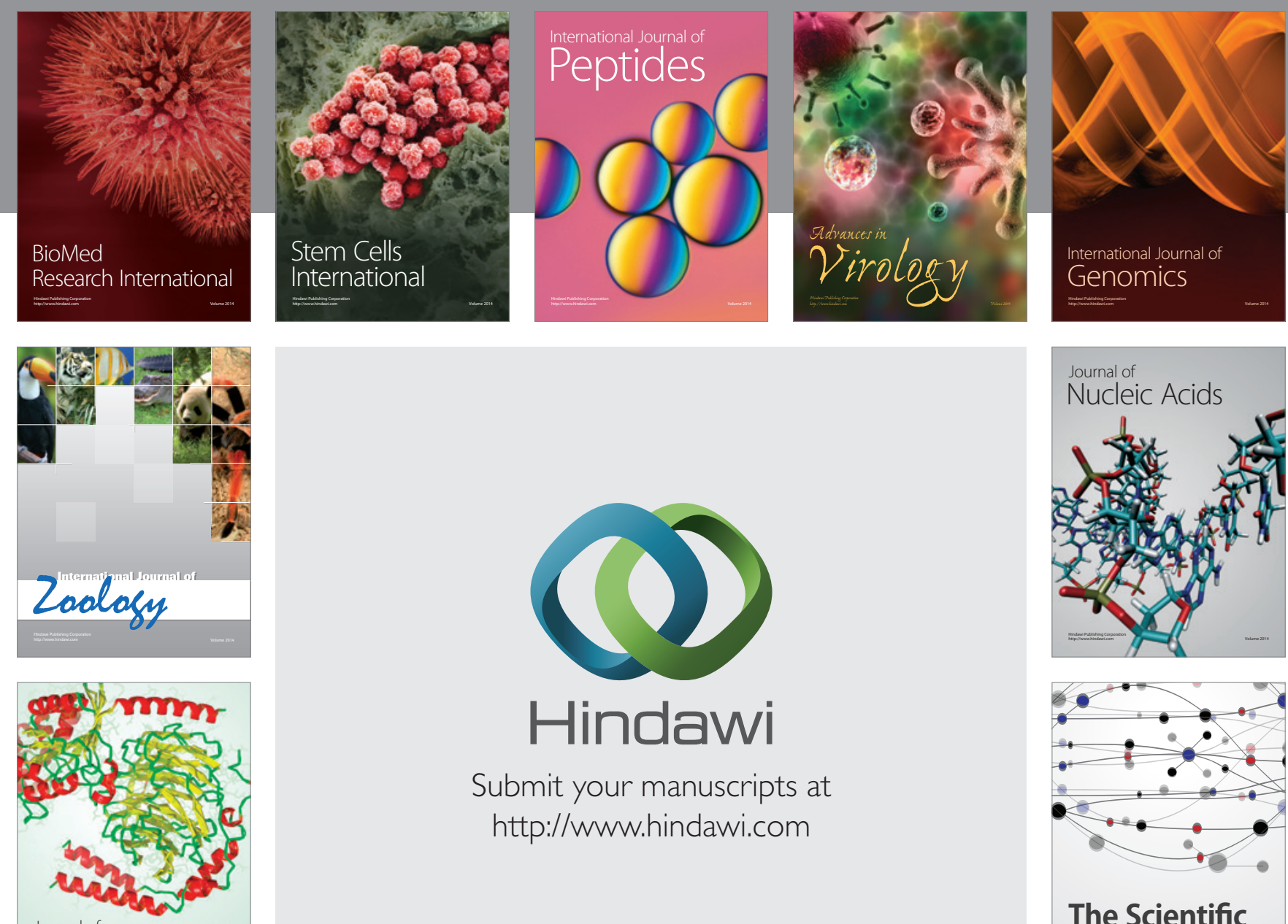

Submit your manuscripts at

http://www.hindawi.com

Journal of
Signal Transduction
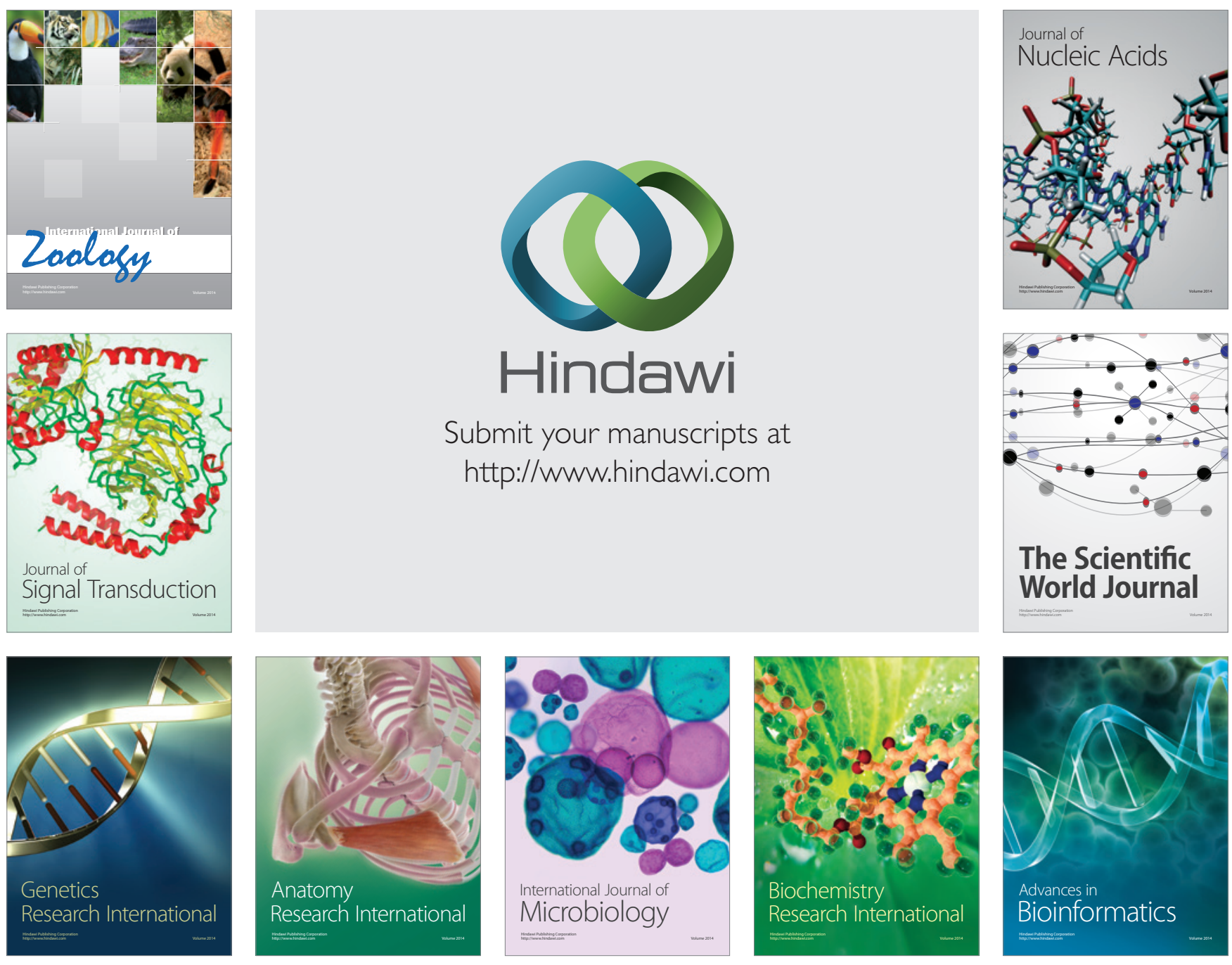

The Scientific World Journal
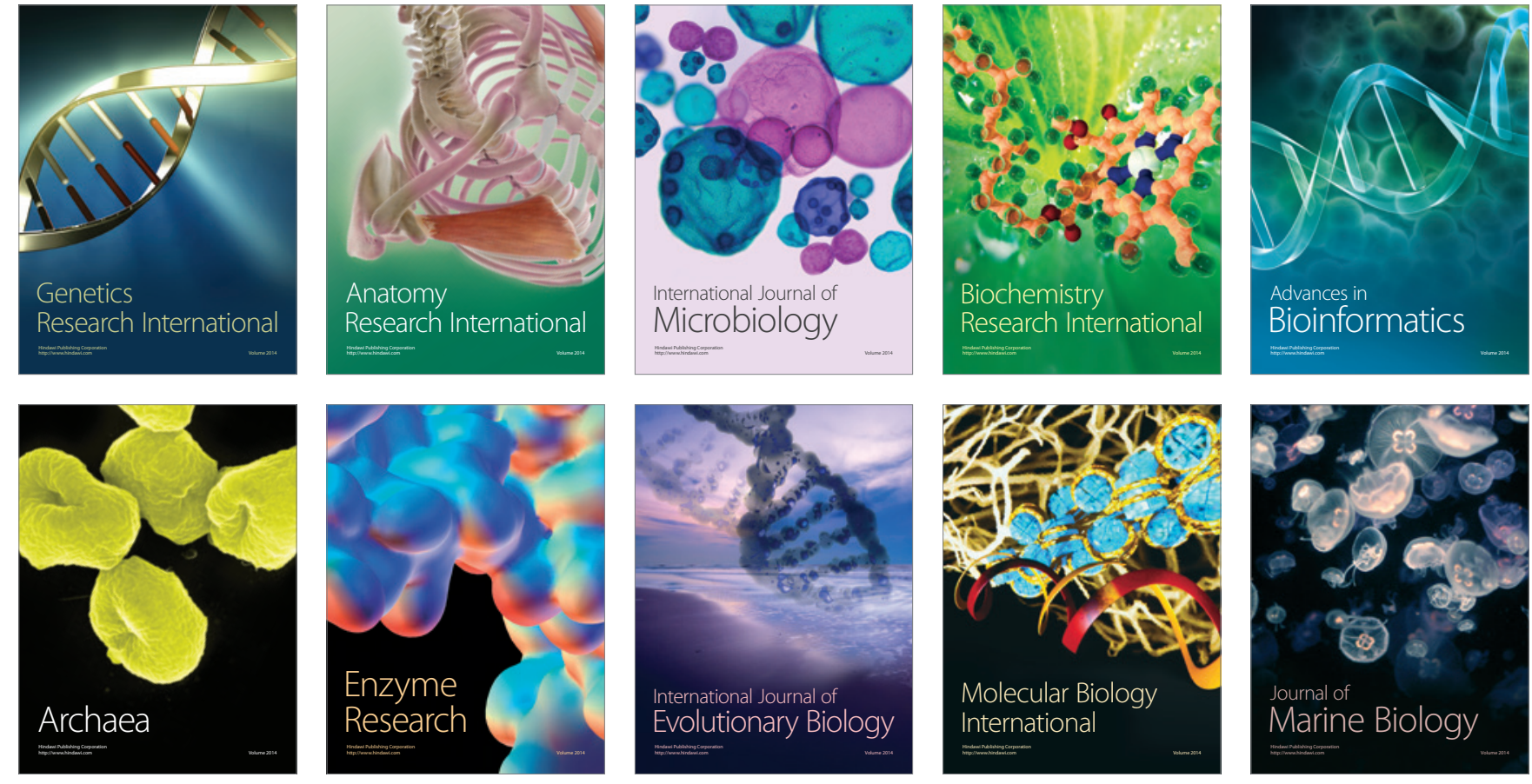